\title{
Effect of essential:total nitrogen ratio on protein utilization in the growing pig
}

\author{
Jaroslav Heger $^{1} *$, Samson Mengesha ${ }^{2}$ and David Vodehnal ${ }^{1}$ \\ ${ }^{1}$ Biofaktory Praha s.r.o., Research Centre of Feed Additives, Na Chvalce 2049, 19300 Praha 9, Czech Republic \\ ${ }^{2}$ Institute of Tropical and Subtropical Agriculture, Czech Agricultural University, Praha, Czech Republic
}

(Received 9 March 1998 - Revised 11 June 1998 - Accepted 18 June 1998)

\begin{abstract}
Two $\mathrm{N}$ balance experiments using growing pigs were conducted to study the effect of essential:total (E:T) $\mathrm{N}$ ratio on $\mathrm{N}$ retention and utilization. Purified diets contained casein and crystalline amino acids as the sole sources of N. E:T values ranged from 0.25 to 0.86 while either the concentration of total $\mathrm{N}$ (Expt. 1) or essential $\mathrm{N}$ (Expt 2) was kept constant. At a constant concentration of total dietary $\mathrm{N}, \mathrm{N}$ retention and total $\mathrm{N}$ utilization were maximized with an $\mathrm{E}: \mathrm{T}$ value of approximately $0 \cdot 6$, while essential $\mathrm{N}$ utilization gradually decreased as E:T increased. At a constant level of essential $\mathrm{N}, \mathrm{N}$ retention remained unchanged until the E:T value reached 0.48 and then decreased. In Expt 2, maximum total $\mathrm{N}$ utilization was attained with an E:T value of 0.66 while $\mathrm{N}$ excretion and essential $\mathrm{N}$ utilization decreased with increased $\mathrm{E}: \mathrm{T}$ value. These results suggest that under conditions of optimal protein utilization, essential amino acids are partially degraded and used for the synthesis of non-essential amino acids.
\end{abstract}

Amino acids: Protein utilization: Pigs

The 'ideal protein' concept is based on a proper balance of amino acids exactly meeting the requirements for growth and maintenance of growing pigs, thereby reducing $\mathrm{N}$ loss due to amino acid excess. In recent years, considerable effort has been directed toward the assessment of the optimum essential amino acid pattern for growing pigs (Agricultural Research Council, 1981; Wang \& Fuller, 1989; Chung \& Baker, 1992; Cole \& Van Lunen, 1994; Baker, 1997). However, essential amino acids supply only about half the total $\mathrm{N}$ ingested by the pig; thus, it is likely that the proportion of non-essential $\mathrm{N}$ sources will also need to be optimized to attain maximum protein utilization and minimum $\mathrm{N}$ excretion.

There are numerous studies indicating the importance of non-essential amino acids in promoting maximal growth and protein deposition (Rose et al. 1948; Stucki \& Harper, 1962; Adkins et al. 1966; Sugahara \& Ariyoshi, 1968). In addition, it has been shown that essential amino acids are not efficient in meeting the requirements for non-specific $\mathrm{N}$ (Adkins et al. 1966; Allen \& Baker, 1974; Featherstone, 1976) and that non-essential amino acids must be provided at a particular proportion of the dietary protein in order to obtain optimum protein utilization. Most experiments aimed at the estimation of optimum essential:total (E:T) N ratio were conducted in rats and chicks where the estimated optimum E:T value ranged between 0.5 and 0.65 (Frost \& Sandy, 1951; Stucki \& Harper, 1961, 1962; Sugahara \& Ariyoshi, 1968; Bedford \& Summers, 1985; Heger et al. 1987). In contrast, information on the optimum E:T value for the growing pig is scarce. Wang \& Fuller (1989) estimated the optimum essential:non-essential amino acids ratio in pigs fed on isonitrogenous diets to be 45:55, which equates to an E:T value of approximately $0 \cdot 42$. Mitchell et al. (1968) studied the effect of adding various levels of glutamic acid to a semipurified diet for piglets and concluded that the optimum E:T value should be at least 0.50. More recently, Lenis et al. (1996) measured $\mathrm{N}$ utilization in growing pigs at three E:T ratios within three dietary $\mathrm{N}$ concentrations and reported that the optimum E:T value increased from 0.45 to 0.55 as the dietary crude protein $(\mathrm{CP})$ concentration decreased from 181 to $138 \mathrm{~g} / \mathrm{kg}$.

In contrast to rat or chick experiments, each of the pig experiments cited earlier was carried out using a relatively narrow range of $\mathrm{E}: \mathrm{T}$ values which might affect the precision of the E:T estimate. The objective of the following two experiments was to examine the response of growing pigs to broader E:T ratios. In addition, since the low E:T values in isonitrogenous diets are necessarily connected with low concentrations of essential amino acids, and

\footnotetext{
Abbreviations: CP, crude protein; E:T, essential nitrogen:total nitrogen.

*Corresponding author: Dr Jaroslav Heger, present address: Biofaktory Praha s.r.o., Generala Piky 3, 61300 Brno, Czech Republic, fax +42 05 510 0329 , email biohp@traveller.cz
} 
consequently with decreased protein deposition, two types of diets were used in which either total $\mathrm{N}$ or essential $\mathrm{N}$ was maintained constant.

\section{Materials and methods \\ Animals and procedures}

Twenty-eight female pigs, initial body weight 46.6 (SE 0.5) $\mathrm{kg}$, from Hampshire boars and Large White $\times$ Landrace sows were used for the two experiments. During each experiment, fourteen pigs were divided into seven pairs with similar body weight. Within each experiment, there were six dietary treatments and three experimental periods, during which six pairs of pigs received three diets successively, using a replicated $3 \times 3$ Latin-square design. The remaining two pigs were randomly allocated to six diets during three periods. Thus, each diet was given to seven pigs throughout the experiment. Pigs were adapted to metabolism cages for $7 \mathrm{~d}$ before the first experimental period. For the first $5 \mathrm{~d}$ during adaptation pigs were fed on a common diet, while experimental diets were offered on days 6 and 7. Each experimental period consisted of a $3 \mathrm{~d}$ preliminary period followed by two successive $48 \mathrm{~h}$ collection periods. Urine was collected using bladder catheters draining into carboys containing $100 \mathrm{ml} 3 \cdot 5 \mathrm{M}-\mathrm{H}_{2} \mathrm{SO}_{4}$. Portions of the $48 \mathrm{~h}$ collections were obtained and immediately analysed for total $\mathrm{N}$. On the last day of the second collection period, faeces were collected by grab sampling, freeze-dried, and finely ground for subsequent analysis of $\mathrm{N}$ and $\mathrm{Cr}_{2} \mathrm{O}_{3}$.

\section{Diets and feeding}

Expt 1: six isonitrogenous (153 g CP/kg), semipurified diets were formulated utilizing casein and crystalline amino acids as the sources of $\mathrm{N}$, such that the $\mathrm{E}: \mathrm{T}$ value varied from 0.25 to 0.86 (Table 1). To prevent the excessive degradation of essential amino acids while allowing rapid growth, the $\mathrm{CP}$ concentration of the diets was slightly less than the minimum required for maximum protein accretion in pigs of the same genotype and of similar body weight (Heger et al. 1997). Essential amino acid ratios corresponded to the ideal protein pattern as given by Fuller et al. (1989) and Chung \& Baker (1992). Arginine was grouped with the essential amino acids since only part of its requirement can be met by in vivo synthesis (Southern \& Baker, 1983; Fuller, 1994). Non-essential $\mathrm{N}$ was supplied by a mixture of L-glutamic acid, glycine and L-proline in the proportions $0 \cdot 6: 0 \cdot 3: 0 \cdot 1$ respectively. In a separate experiment the metabolizable energy content of diet T4, estimated using five pigs, was found to be 15.5 (SE 0.1) MJ/kg (J Heger, S Mengesha and D Vodehnal, unpublished results). Expt 2: as in Expt 1, six semipurified diets were prepared to produce E:T values ranging from 0.25 to 0.86 . Unlike Expt 1, however, the concentrations of essential amino acids were kept constant

Table 1. Expt 1. Composition of diets and calculated nutrient contents $(\mathrm{g} / \mathrm{kg})$ at constant dietary total nitrogen content

\begin{tabular}{|c|c|c|c|c|c|c|}
\hline & \multicolumn{6}{|c|}{ Dietary treatment } \\
\hline & T1 & T2 & T3 & T4 & T5 & T6 \\
\hline Casein* & $52 \cdot 0$ & $52 \cdot 0$ & $52 \cdot 0$ & $52 \cdot 0$ & $52 \cdot 0$ & $52 \cdot 0$ \\
\hline Cellulose & $60 \cdot 0$ & $60 \cdot 0$ & $60 \cdot 0$ & $60 \cdot 0$ & $60 \cdot 0$ & $60 \cdot 0$ \\
\hline Sucrose & $150 \cdot 0$ & $150 \cdot 0$ & $150 \cdot 0$ & $150 \cdot 0$ & $150 \cdot 0$ & $150 \cdot 0$ \\
\hline Soyabean oil & 40.0 & 40.0 & 40.0 & 40.0 & 40.0 & 40.0 \\
\hline L-Arginine & 1.13 & 2.50 & 3.87 & 5.23 & $6 \cdot 60$ & 7.97 \\
\hline L-Histidine & 0.77 & 1.84 & 2.92 & 3.99 & 5.07 & $6 \cdot 14$ \\
\hline L-Isoleucine & 1.66 & 3.61 & 5.56 & 7.52 & 9.47 & 11.42 \\
\hline L-Leucine & $3 \cdot 10$ & $6 \cdot 68$ & $10 \cdot 26$ & $13 \cdot 85$ & $17 \cdot 43$ & 21.01 \\
\hline L-Lysine- $\mathrm{HCl}$ & 3.73 & 7.80 & 11.87 & 15.94 & $20 \cdot 01$ & 24.08 \\
\hline DL-Methionine & 2.48 & 4.43 & 6.39 & 8.34 & $10 \cdot 30$ & $12 \cdot 25$ \\
\hline L-Phenylalanine & 1.71 & 4.97 & 8.23 & 11.48 & 14.74 & 18.00 \\
\hline L-Threonine & 2.44 & 4.56 & 6.67 & 8.79 & $10 \cdot 90$ & 13.02 \\
\hline L-Tryptophan & 0.78 & 1.43 & 2.08 & $2 \cdot 74$ & 3.39 & 4.04 \\
\hline L-Valine & 1.73 & 4.01 & $6 \cdot 30$ & 8.58 & $10 \cdot 87$ & $13 \cdot 15$ \\
\hline NEAA mixture† & $120 \cdot 4$ & $96 \cdot 3$ & $72 \cdot 2$ & 48.2 & $24 \cdot 1$ & 0.0 \\
\hline Mineral mixture & 61.5 & 61.5 & 61.5 & 61.5 & 61.5 & 61.5 \\
\hline Premix§ & $5 \cdot 0$ & $5 \cdot 0$ & $5 \cdot 0$ & $5 \cdot 0$ & 5.0 & $5 \cdot 0$ \\
\hline Chromic oxide & $4 \cdot 0$ & 4.0 & $4 \cdot 0$ & 4.0 & 4.0 & 4.0 \\
\hline Starch & $487 \cdot 6$ & $489 \cdot 4$ & $491 \cdot 1$ & $492 \cdot 9$ & $494 \cdot 7$ & $496 \cdot 4$ \\
\hline Total N & 24.5 & 24.5 & 24.5 & 24.5 & 24.5 & 24.5 \\
\hline Essential N & $6 \cdot 1$ & $9 \cdot 1$ & $12 \cdot 1$ & $15 \cdot 1$ & $18 \cdot 1$ & $21 \cdot 0$ \\
\hline $\mathrm{E}: \mathrm{T}$ & 0.25 & 0.37 & 0.49 & 0.62 & 0.74 & 0.86 \\
\hline
\end{tabular}

NEAA, non-essential amino acids; $\mathrm{E}: \mathrm{T}$, essential $\mathrm{N}$ :total $\mathrm{N}$.

* Contained $(\mathrm{g} / \mathrm{kg})$ : N 132.8, arginine $31 \cdot 7$, histidine $27 \cdot 3$, isoleucine 44.4, leucine $80 \cdot 4$, lysine $70 \cdot 0$, methionine

25.9 , cystine 3.0 , phenylalanine 43.6 , tyrosine 51.0 , threonine 35.9 , tryptophan 10.5 , valine 55.7 .

† Contained (g/kg): L-glutamic acid 600, glycine 300, L-proline 100.

†Provided the following (g/kg diet): $\mathrm{Ca}_{3}\left(\mathrm{PO}_{4}\right)_{2} 40, \mathrm{NaCl} 4, \mathrm{MgO} 3, \mathrm{~K}_{2} \mathrm{CO}_{3} 7, \mathrm{NaHCO}_{3} 7.5$.

$\S$ Provided the following ( $\mathrm{mg} / \mathrm{kg}$ diet): retinol 1.2 , cholecalciferol 25, $\alpha$-tocopherol 10, menadione 0.2 , riboflavin 4 ,

pyridoxine 2.5 , D-pantothenic acid 10 , niacin 20 , folic acid 0.5 , biotin 0.1 , cyanocobalamin $30 \mu$, choline 500 ,

Fe 92, Zn 103, Mn 40, Cu 19, Co 0.5, Se 0.16. 
Table 2. Expt 2. Composition of diets and calculated nutrient contents $(\mathrm{g} / \mathrm{kg})$ at constant dietary essential nitrogen content

\begin{tabular}{|c|c|c|c|c|c|c|}
\hline & \multicolumn{6}{|c|}{ Dietary treatment } \\
\hline & E1 & E2 & E3 & E4 & E5 & E6 \\
\hline Casein* & 103.0 & 87.0 & $71 \cdot 0$ & $55 \cdot 0$ & 39.0 & $23 \cdot 0$ \\
\hline Cellulose & 60.0 & 60.0 & 60.0 & $60 \cdot 0$ & $60 \cdot 0$ & $60 \cdot 0$ \\
\hline Sucrose & $150 \cdot 0$ & $150 \cdot 0$ & $150 \cdot 0$ & $150 \cdot 0$ & $150 \cdot 0$ & $150 \cdot 0$ \\
\hline Soyabean oil & $40 \cdot 0$ & 40.0 & $40 \cdot 0$ & $40 \cdot 0$ & $40 \cdot 0$ & 40.0 \\
\hline L-Arginine & 0.91 & 1.42 & 1.94 & 2.45 & 2.96 & 3.47 \\
\hline L-Histidine & 0.47 & 0.91 & 1.35 & 1.79 & $2 \cdot 23$ & 2.67 \\
\hline L-Isoleucine & 1.38 & $2 \cdot 10$ & $2 \cdot 81$ & 3.53 & 4.25 & 4.97 \\
\hline L-Leucine & 2.64 & 3.93 & 5.23 & 6.54 & 7.83 & 9.14 \\
\hline L-Lysine-HCl & 3.41 & 4.82 & $6 \cdot 23$ & $7 \cdot 65$ & 9.05 & $10 \cdot 48$ \\
\hline DL-Methionine & 3.00 & 3.47 & 3.94 & 4.40 & 4.87 & $5 \cdot 34$ \\
\hline L-Phenylalanine & 0.16 & 1.69 & 3.22 & 4.75 & $6 \cdot 28$ & $7 \cdot 81$ \\
\hline L-Threonine & 2.77 & 3.35 & 3.93 & 4.51 & 5.09 & $5 \cdot 67$ \\
\hline L-Tryptophan & 0.91 & 1.08 & 1.25 & 1.42 & 1.59 & 1.76 \\
\hline L-Valine & 1.21 & $2 \cdot 11$ & 3.01 & 3.91 & 4.81 & 5.71 \\
\hline NEAA mixture* & $163 \cdot 0$ & 76.5 & $37 \cdot 0$ & $16 \cdot 4$ & 5.4 & 0.0 \\
\hline Mineral mixture* & 61.5 & 61.5 & 61.5 & 61.5 & 61.5 & 61.5 \\
\hline Premix* & $5 \cdot 0$ & $5 \cdot 0$ & 5.0 & $5 \cdot 0$ & 5.0 & $5 \cdot 0$ \\
\hline Chromic oxide & 4.0 & 4.0 & 4.0 & 4.0 & 4.0 & 4.0 \\
\hline Starch & $396 \cdot 6$ & $491 \cdot 1$ & $538 \cdot 6$ & $567 \cdot 2$ & $586 \cdot 1$ & 599.5 \\
\hline Total N & $36 \cdot 1$ & $24 \cdot 4$ & $18 \cdot 4$ & $14 \cdot 8$ & $12 \cdot 4$ & $10 \cdot 7$ \\
\hline Essential N & 9.2 & $9 \cdot 2$ & 9.2 & 9.2 & $9 \cdot 2$ & $9 \cdot 2$ \\
\hline $\mathrm{E}: \mathrm{T}$ & 0.25 & 0.38 & 0.50 & 0.62 & 0.74 & 0.86 \\
\hline
\end{tabular}

NEAA, non-essential amino acids; E:T, essential N:total N.

${ }^{*}$ For details, see Table 1.

with the changes in E:T made by changing the proportion of non-essential amino acid mixture. As a consequence, the total dietary CP decreased from 226 to $67 \mathrm{~g} / \mathrm{kg}$ (Table 2). Since the process of deamination and elimination of excessive protein requires energy thus decreasing the metabolizable energy content in high-protein diets, metabolizable energy was calculated for diets E1 to E6 using the estimated value for diet $\mathrm{T} 4$ and a regression equation given by Noblet (1996). The calculated lysine:metabolizable energy values ranged between 0.63 and 0.65 , thus suggesting that energy was not a limiting factor in Expt 2. Pigs were fed twice daily at 07.30 and 15.30 hours in two equal meals at a daily rate of $80 \mathrm{~g} / \mathrm{kg}^{0.75}$. Water was provided according to a total feed:water ratio of $1: 2$, both before and after each feeding.

\section{Measurements}

The amino acid composition of casein was analysed by ion-exchange chromatography (Llames \& Fontaine, 1994), the $\mathrm{Cr}_{2} \mathrm{O}_{3}$ content of diets and faeces by atomic absorption spectroscopy (Petry \& Rapp, 1970/71), and total N of the diets, faeces and urine by macro-Kjeldahl methodology (Association of Official Analytical Chemists, 1984). Apparent $\mathrm{N}$ digestibility, $\mathrm{N}$ excretion and $\mathrm{N}$ retention values were then calculated. Dietary $\mathrm{N}$ utilization was calculated as the proportion of $\mathrm{N}$ retained compared with $\mathrm{N}$ consumed. Calculation of essential $\mathrm{N}$ retention and utilization was based on amino acid composition of protein deposited in the empty body of female pigs at similar body weights (Bikker et al. 1994), with the value for tryptophan obtained from whole-body amino acid composition in growing pigs (Kyriazakis et al. 1993).

\section{Statistical analysis}

Data were subjected to ANOVA (Steel \& Torrie, 1980) with differences between means assessed using the least significant difference test. Linear and polynomial functions were fitted to experimental data to describe the nature of the response variable and to predict maximum values. The bentstick model (Robbins et al. 1979) was used to calculate the breakpoint response.

\section{Results}

Expt 1: the effects of varying the E:T value from 0.25 to 0.86 at a constant dietary concentration of total $\mathrm{N}$ are summarized in Table 3. Feed intake, and consequently $\mathrm{N}$ intake, was slightly depressed in pigs fed on diets having the highest E:T value. Apparent $\mathrm{N}$ digestibility was not affected by dietary E:T value. Total $\mathrm{N}$ retention $\left(\mathrm{g} / \mathrm{kg}^{0.75}\right)$ and total $\mathrm{N}$ utilization ( $\mathrm{N}$ retention/ $\mathrm{N}$ intake) increased as the E:T value increased, reaching a maximum at an E:T value of 0.62 (diet T4), and then decreased (Fig. 1). Essential $\mathrm{N}$ utilization gradually decreased with increasing E:T value. The responses of total and essential $\mathrm{N}$ utilization to varying E:T values are shown in Fig. 2. The calculated optimum E:T values corresponding to the maximum $\mathrm{N}$ retention and total $\mathrm{N}$ utilization were 0.61 and 0.58 respectively. There was no significant effect of the experimental period on any response variable $(P>0 \cdot 1)$.

Expt 2: the effects of varying the E:T value from $0 \cdot 25$ to 0.86 at a constant dietary concentration of essential $\mathrm{N}$ are summarized in Table 4. Similar to Expt 1, there was a decrease in feed and $\mathrm{N}$ intake in pigs receiving diets with the high E:T values. Apparent $\mathrm{N}$ digestibility decreased 
Table 3. Expt 1. Effect of essential nitrogen:total nitrogen $(E: T)$ value on nitrogen utilization at constant dietary total nitrogen content

(Mean values for seven pigs with their pooled standard errors)

\begin{tabular}{|c|c|c|c|c|c|c|c|}
\hline \multirow[b]{2}{*}{$\begin{array}{l}\text { Total } N(\mathrm{~g} / \mathrm{kg}) \ldots \\
\text { Essential } N(\mathrm{~g} / \mathrm{kg}) \ldots \\
\text { E:T value... }\end{array}$} & \multicolumn{6}{|c|}{ Dietary treatment } & \multirow[b]{2}{*}{$\begin{array}{c}\text { Pooleo } \\
\text { SE }\end{array}$} \\
\hline & $\begin{array}{c}\mathrm{T} 1 \\
24.5 \\
6 \cdot 1 \\
0.25\end{array}$ & $\begin{array}{c}\text { T2 } \\
24.5 \\
9.1 \\
0.37\end{array}$ & $\begin{array}{c}\text { T3 } \\
24.5 \\
12.1 \\
0.49\end{array}$ & $\begin{array}{c}\text { T4 } \\
24.5 \\
15.1 \\
0.62\end{array}$ & $\begin{array}{c}\text { T5 } \\
24.5 \\
18.0 \\
0.74\end{array}$ & $\begin{array}{c}\text { T6 } \\
24.5 \\
21.0 \\
0.86\end{array}$ & \\
\hline $\begin{array}{l}\text { Food intake }\left(\mathrm{g} / \mathrm{kg}^{0.75}\right) \\
\mathrm{N} \text { intake }\left(\mathrm{g} / \mathrm{kg}^{0.75}\right) \\
\mathrm{N} \text { digestibility } \\
\mathrm{N} \text { retention }\left(\mathrm{g} / \mathrm{kg}^{0.75}\right) \\
\mathrm{N} \text { excretion }\left(\mathrm{g} / \mathrm{kg}^{0.75}\right) \\
\text { Total N utilization* } \\
\text { Essential N utilization* }\end{array}$ & $\begin{array}{l}85 \cdot 3 \\
2 \cdot 07 \\
0.95 \\
0.86^{\mathrm{a}} \\
1.21^{\mathrm{a}} \\
0.41^{\mathrm{a}} \\
0.74^{\mathrm{a}}\end{array}$ & $\begin{array}{l}85.3 \\
2.07 \\
0.95 \\
1.01^{\mathrm{b}} \\
1.06^{\mathrm{ab}} \\
0.49^{\mathrm{b}} \\
0.59^{\mathrm{b}}\end{array}$ & $\begin{array}{c}84.7 \\
2.06 \\
0.95 \\
1.09^{b c} \\
0.97^{b} \\
0.53^{b} \\
0.48^{c}\end{array}$ & $\begin{array}{c}85 \cdot 2 \\
2.07 \\
0.95 \\
1.11^{\mathrm{c}} \\
0.96^{\mathrm{b}} \\
0.54^{\mathrm{b}} \\
0.39^{\mathrm{d}}\end{array}$ & $\begin{array}{l}84.1 \\
2.04 \\
0.95 \\
1.05^{\mathrm{bc}} \\
0.99^{\mathrm{b}} \\
0.52^{\mathrm{b}} \\
0.31^{\mathrm{e}}\end{array}$ & $\begin{array}{l}81.6 \\
1.98 \\
0.95 \\
1.00^{\mathrm{b}} \\
0.98^{\mathrm{b}} \\
0.51^{\mathrm{b}} \\
0.26^{\mathrm{f}}\end{array}$ & $\begin{array}{l}1.084 \\
0.026 \\
0.001 \\
0.013 \\
0.024 \\
0.007 \\
0.007\end{array}$ \\
\hline
\end{tabular}

a,b,c,d,e,f Mean values within a row not sharing a common superscript letter were significantly different, $P<0.05$.

* Digestibility and utilization values are relative to intake.

as dietary E:T value increased. Total $\mathrm{N}$ retention remained relatively unchanged when $\mathrm{E}: \mathrm{T}$ increased from 0.25 to $0 \cdot 50$ (diets E1-E3), and then gradually decreased (Fig. 1). Total $\mathrm{N}$ utilization increased up to an E:T value of $0.62-$ $0 \cdot 70$, and then decreased, while essential $\mathrm{N}$ utilization decreased with increasing E:T value (Fig. 3). The breakpoint in $\mathrm{N}$ retention was at a calculated $\mathrm{E}: \mathrm{T}$ value of 0.48 , while the maximum total $\mathrm{N}$ utilization was attained with an E:T value of 0.66 . The confidence intervals for these points were $0.38-0.50$ and $0.52-0.76$ respectively, thus indicating a significant difference between the two estimates $(P<0 \cdot 05)$. The response variables were not significantly affected by the experimental period $(P>0 \cdot 1)$.

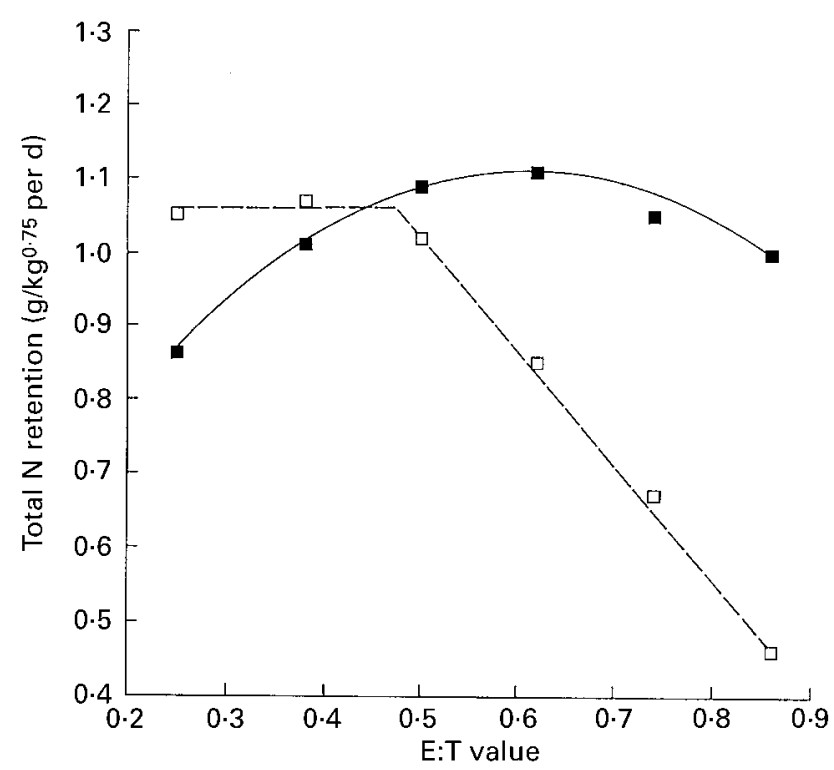

Fig. 1. The relationship between essential nitrogen:total nitrogen $(\mathrm{E}: \mathrm{T})$ value and nitrogen retention at constant concentration of total (घ) or essential $(\square)$ nitrogen in the diet. (-) Plotted from the equation $y=0.42+2.26 x-1.86 x^{2} ; r^{2} 0.50 ;$ SE 0.081 . (- - -) Plotted from the equations $y_{1}=1.06 ; y_{2}=1.80-1.56 x ; r^{2} 0.78 ;$ SE 0.113 .

\section{Discussion}

The decrease in apparent $\mathrm{N}$ digestibility with increasing $\mathrm{E}: \mathrm{T}$ value in Expt 2 was due to the decreased concentration of total $\mathrm{N}$ in the diet. This was expected since the proportion of $\mathrm{N}$ of metabolic origin in faeces increases as the dietary protein concentration decreases, thus changing the relationship between dietary and faecal N (Fan et al. 1994).

As in experiments with rats (Stucki \& Harper, 1962; Heger et al. 1987), there was a curvilinear relationship between $E: T$ and $N$ retention when the concentration of total dietary $\mathrm{N}$ was held constant (Expt 1). Even though the dose-response curve was flat in the region around the

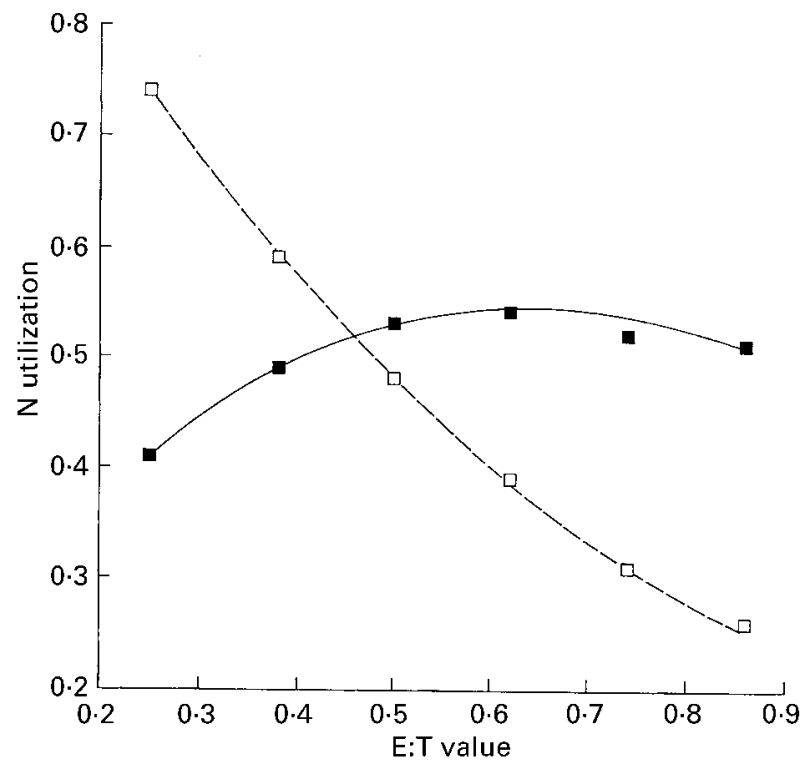

Fig. 2. The relationship between essential nitrogen:total nitrogen $(E: T)$ value and total $(\boldsymbol{\square})$ or essential $(\square)$ nitrogen utilization at constant concentration of total nitrogen in the diet. (-) Plotted from the equation $y=0.06+2.07 x-2.87 x^{2}+1.24 x^{3} ; r^{2} 0.46 ;$ SE 0.043 . (- - ) Plotted from the equation $y=1.10-1.64 x+0.78 x^{2} ; r^{2} 0.94$; SE 0.041 . 
Table 4. Expt 2. Effect of essential nitrogen:total nitrogen $(E: T)$ value on nitrogen utilization at constant dietary essential nitrogen content

(Mean values for seven pigs with their pooled standard errors)

\begin{tabular}{|c|c|c|c|c|c|c|c|}
\hline \multirow[b]{2}{*}{$\begin{array}{l}\text { Total } N(\mathrm{~g} / \mathrm{kg}) \ldots \\
\text { Essential } N(\mathrm{~g} / \mathrm{kg}) \ldots \\
\text { E:T value ... }\end{array}$} & \multicolumn{6}{|c|}{ Dietary treatment } & \multirow[b]{2}{*}{$\begin{array}{c}\text { Pooled } \\
\text { SE }\end{array}$} \\
\hline & $\begin{array}{c}E 1 \\
36 \cdot 1 \\
9.2 \\
0.25\end{array}$ & $\begin{array}{c}E 2 \\
24.4 \\
9.2 \\
0.38\end{array}$ & $\begin{array}{c}\text { E3 } \\
18.4 \\
9.2 \\
0.50\end{array}$ & $\begin{array}{c}E 4 \\
14.8 \\
9.2 \\
0.62\end{array}$ & $\begin{array}{c}\text { E5 } \\
12 \cdot 4 \\
9.2 \\
0.74\end{array}$ & $\begin{array}{c}\text { E6 } \\
10.7 \\
9.2 \\
0.86\end{array}$ & \\
\hline $\begin{array}{l}\text { Food intake }\left(\mathrm{g} / \mathrm{kg}^{0.75}\right) \\
\mathrm{N} \text { intake }\left(\mathrm{g} / \mathrm{kg}^{0.75}\right) \\
\mathrm{N} \text { digestibility* } \\
\mathrm{N} \text { retention }\left(\mathrm{g} / \mathrm{kg}^{0.75}\right) \\
\mathrm{N} \text { excretion }\left(\mathrm{g} / \mathrm{kg}^{0.75}\right) \\
\text { Total } \mathrm{N} \text { utilization* } \\
\text { Essential N utilization* }\end{array}$ & $\begin{array}{c}78 \cdot 7^{\mathrm{abc}} \\
2.82^{\mathrm{a}} \\
0.97^{\mathrm{a}} \\
1.05^{\mathrm{a}} \\
1.77^{\mathrm{a}} \\
0.37^{\mathrm{a}} \\
0.65^{\mathrm{a}}\end{array}$ & $\begin{array}{l}85 \cdot 6^{\mathrm{a}} \\
2.07^{\mathrm{b}} \\
0.94^{\mathrm{b}} \\
1.07^{\mathrm{a}} \\
1.00^{\mathrm{b}} \\
0.52^{\mathrm{b}} \\
0.61^{\mathrm{ab}}\end{array}$ & $\begin{array}{l}85 \cdot 9^{\mathrm{a}} \\
1.58^{\mathrm{c}} \\
0.93^{\mathrm{b}} \\
1.02^{\mathrm{ab}} \\
0.56^{\mathrm{c}} \\
0.65^{\mathrm{cd}} \\
0.57^{\mathrm{b}}\end{array}$ & $\begin{array}{r}83 \cdot 6^{\mathrm{ab}} \\
1.23^{\mathrm{d}} \\
0.91^{\mathrm{c}} \\
0.85^{\mathrm{b}} \\
0.38^{\mathrm{d}} \\
0.69^{\mathrm{d}} \\
0.49^{\mathrm{c}}\end{array}$ & $\begin{array}{r}76 \cdot 8^{\mathrm{bc}} \\
0.95^{\mathrm{e}} \\
0.90^{\mathrm{c}} \\
0.67^{\mathrm{c}} \\
0.28^{\mathrm{d}} \\
0.70^{\mathrm{d}} \\
0.42^{\mathrm{d}}\end{array}$ & $\begin{array}{l}73.0^{c} \\
0.78^{f} \\
0.87^{d} \\
0.46^{d} \\
0.32^{d} \\
0.59^{b c} \\
0.30^{e}\end{array}$ & $\begin{array}{l}1 \cdot 110 \\
0.020 \\
0.003 \\
0.018 \\
0.018 \\
0.001 \\
0.009\end{array}$ \\
\hline
\end{tabular}

a,b,c,d,e,f Mean values within a row not sharing a common superscript letter were significantly different, $P<0.05$.

* Digestibility and utilization values are relative to intake.

optimum, there was a significant decrease in $\mathrm{N}$ retention as the E:T values approached the highest levels tested. A marked decrease in $\mathrm{N}$ retention was also observed in our previous experiments with rats (Heger et al. 1987; Heger, 1990) when only essential amino acids were used as a source of $\mathrm{N}$ (E:T value of 1.0). Whereas the poor $\mathrm{N}$ retention at low E:T values was clearly due to the deficiency of essential amino acids, the effect of high $E: T$ values is not fully understood. It has been suggested that the synthesis rate of one or more amino acids commonly classified as non-essential may be insufficient to maintain maximal growth rate (Adkins et al. 1966; Harper, 1974), thus causing a reduction in $\mathrm{N}$ retention. Ball et al. (1986) reported that to obtain maximum protein deposition in $2.5 \mathrm{~kg}$ pigs,

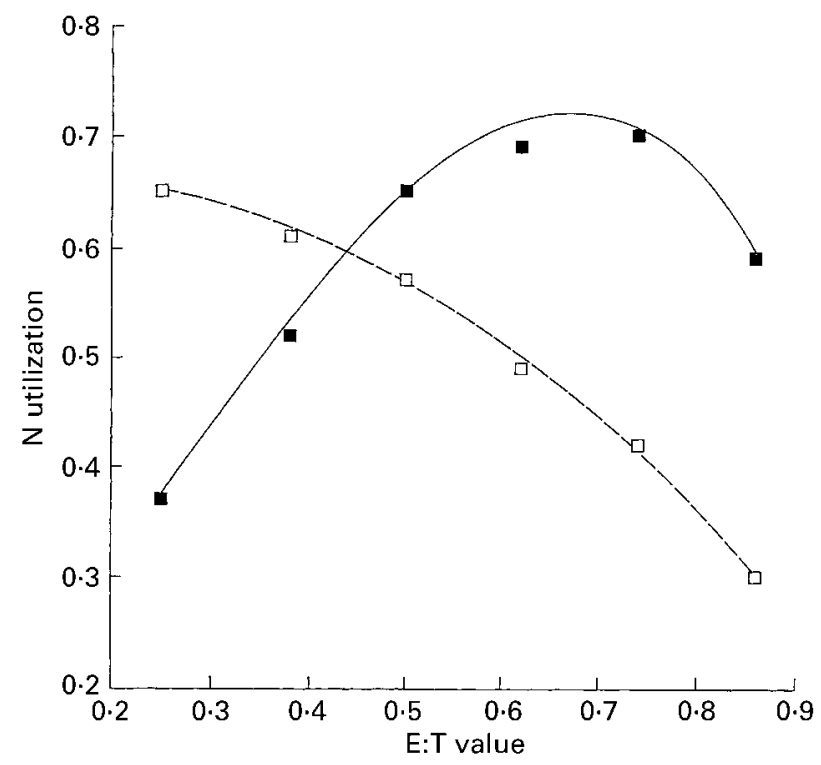

Fig. 3. The relationship between essential nitrogen:total nitrogen $(E: T)$ value and total $(\square)$ or essential $(\square)$ nitrogen utilization at constant concentration of essential nitrogen in the diet. (-) Plotted from the equation $y=0.10+0.87 x+1.54 x^{2}-2.18 x^{3} ; r^{2} 0.71$; SE 0.071 . (- - ) Plotted from the equation $y=0.65+0.15 x-0.65 x^{2}$; $r^{2} 0.83$; SE 0.054 . proline must be added to the diet. In contrast, Chung \& Baker (1993) demonstrated that the young pig could synthesize adequate quantities of proline endogenously. However, it appears that in a purified diet lacking both proline and its main precursor, glutamic acid, proline may become a limiting factor for maximum $\mathrm{N}$ retention. This is supported by the studies of Roth et al. (1994a) who found that the deletion of proline or glutamic acid from a purified diet resulted in reduced $\mathrm{N}$ retention in young pigs.

In Expt 1, the lower $\mathrm{N}$ retention at high $\mathrm{E}: \mathrm{T}$ values might also be due to decreased utilization of essential amino acids as sources of non-essential N. Although it has been shown that all essential amino acids are converted into nonessential amino acids (Aqvist, 1951), experiments evaluating this hypothesis from the quantitative point of view suggest that the conversion efficiency of some essential amino acids is low. Comparing the efficacy of various sources of non-essential $\mathrm{N}$ in chicks, Allen \& Baker (1974) reported that arginine and lysine were poorly converted to non-essential $\mathrm{N}$. In rats, low conversion efficiencies have been observed for lysine, arginine and methionine plus cystine, while other essential amino acids appeared to be well utilized (Heger, 1990). No information on the efficacy of amino acids supplying non-essential $\mathrm{N}$ has been reported in pigs. Taylor et al. (1996) studied the importance of non-essential amino acids in kittens and showed that diets containing only essential amino acids could support nearmaximal growth, as long as an excess of methionine and arginine was avoided. They concluded that the poor growth associated with diets having high $\mathrm{E}: \mathrm{T}$ values was the result of an adverse effect of excesses of methionine and other amino acids, and not the inability to synthesize non-essential amino acids. However, Cieslak \& Benevenga (1984a,b) using rats and Fisher et al. (1960) using chicks showed that the negative effect of amino acid excess on growth rate was almost entirely due to changes in voluntary feed intake, which was not the case in the previously-mentioned rat studies. On the other hand, D'Mello (1994) reported that metabolic interactions between amino acids may result in a reduction of protein utilization even at constant feed intake. Further studies are needed to elucidate this problem. 
When total dietary $\mathrm{N}$ was held constant (Expt 1), maximum $\mathrm{N}$ retention was attained with an E:T value of 0.61. This is considerably higher than the value reported by Wang \& Fuller (1989) who found the minimum E:T value (recalculated from essential:non-essential amino acid ratio) required for maximum efficiency of $\mathrm{N}$ retention was approximately $0 \cdot 42$. However, these authors estimated the optimum essential:non-essential amino acid value using a linear-plateau model fitted to data obtained with four E:T values ranging from about 0.33 to 0.53 . Thus, different methods of interpreting the response data might contribute at least partly to differences found between the present experiments and those by Wang \& Fuller (1989). The optimum E:T value found by Lenis et al. (1996) for dietary CP concentration similar to that used in the present study was $0 \cdot 50$. This optimum E:T value was estimated by fitting a parabola to $\mathrm{N}$ retention data taken from the experiment in which E:T values ranged from $0 \cdot 35$ to 0.59 . As shown by Morris (1989), a restricted set of data could substantially underestimate the calculated optimum in the parabolic model since the quadratic curve is very sensitive to the range of input values and tends to estimate the maximum (or minimum) in the middle of the range tested. Therefore, an optimum E:T value estimated within a wider range of values should be more reliable.

$\mathrm{N}$ retention in pigs in response to changes in E:T value at constant concentration of essential N (Expt 2) differed from that at constant total $\mathrm{N}$ (Expt 1, Fig. 1). At a constant concentration of essential $\mathrm{N}, \mathrm{N}$ retention was maintained at the same level until either non-essential or total $\mathrm{N}$ became limiting, whereupon $\mathrm{N}$ retention decreased linearly. It is interesting to note that the E:T value breakpoint of 0.48 for total $\mathrm{N}$ retention (Fig. 1) was significantly lower than the E:T value of 0.66 required for maximum total $\mathrm{N}$ utilization (Fig. 3), such that more non-essential $\mathrm{N}$ was required for maximizing $\mathrm{N}$ utilization. A similar conclusion can be drawn from other $\mathrm{N}$ balance experiments conducted both on pigs (Mitchell et al. 1968; Roth et al. 1994b) and rats (Heger et al. 1987). These observations suggest that nonessential $\mathrm{N}$ has a 'sparing effect' on the utilization of essential amino acids. Indeed, the utilization of essential $\mathrm{N}$ increased as the concentration of non-essential $\mathrm{N}$ increased (lower E:T values) up to the lowest E:T values (Fig. 3). Similar results were obtained in a study by van Diepen et al. (1995). However, it should be noted that, in both cases, the retention of essential $\mathrm{N}$ was estimated indirectly from the amino acid pattern of body protein and was based on the assumption that body protein composition was not affected by dietary treatments. To date, it is not clear whether a surplus of non-essential amino acids can cause such changes. In addition, there is a possibility that the increased $\mathrm{N}$ retention in short-term balance experiments might be due to the adaptive response to the excessive intake of non-essential amino acids. It has been shown that the size and protein content of internal organs increased with increasing supply of dietary protein (Munro, 1964; Noblet et al. 1987; Kerr et al. 1995). An increased N retention was observed in chicks (Shapiro \& Fisher, 1962) and pigs (Kerr \& Easter, 1995) when non-essential amino acids were added to the diet. Even though the accumulation of the 'labile protein' in the body is a matter of a few days after changing the diet (Munro, 1964), its effect on the results of $\mathrm{N}$ balance cannot be fully excluded.

The changes in the utilization of total and essential $\mathrm{N}$ were similar in both experiments. The low utilization of total $\mathrm{N}$ at low E:T values was due to the lack of essential amino acids either as a result of their low dietary concentrations at constant total $\mathrm{N}$ (Expt 1) or their conversion into non-essential amino acids at constant essential N (Expt 2). Utilization of essential $\mathrm{N}$ decreased as its proportion in the diet increased, and at optimum E:T values for $\mathrm{N}$ retention or total $\mathrm{N}$ utilization, the utilization of essential $\mathrm{N}$ was substantially lower than for total $\mathrm{N}$. This implies that non-essential amino acids are synthesized from essential amino acids under these conditions. Studies in both pigs (van Diepen et al. 1955) and rats (Heger, 1990) support this idea. As discussed extensively elsewhere (Heger \& Frydrych, 1989), this phenomenon is presumably a consequence of mechanisms regulating the degradation of amino acids in the body. It is generally known that essential amino acids are conserved when they are in short supply (Yamashita \& Ashida, 1969; Said \& Hegsted, 1970). However, isotope studies show that a part of most essential amino acids is degraded, even at very low levels of intake (Kang-Lee \& Harper, 1977; Harper \& Benjamin, 1984; Tanaka et al. 1995). This may explain why the utilization of essential $\mathrm{N}$ was lower than 1.0 at low E:T values in the study at constant total $\mathrm{N}$, even though it is assumed there would be metabolic pressure on maximum utilization of essential amino acids. Our results suggest that the inevitable loss of essential $\mathrm{N}$ may be counterbalanced by the synthesis of non-essential amino acids using the degraded $\mathrm{N}$, thus maximizing the overall efficiency of utilization of ingested protein.

Defining the optimum E:T value could be useful as a part of the 'ideal protein' concept provided the optimum is independent of the variety of factors influencing amino acid requirements. It is not yet clear whether this assumption is valid. Therefore, it seems to be worth considering the potential factors which may affect the optimum E:T estimate. First, the methodology applied may play a significant role. When total dietary $\mathrm{N}$ is kept constant, the changes in the E:T value result in changes in essential $\mathrm{N}$ concentrations. Since the essential $\mathrm{N}$ intake relative to the requirement is a major factor influencing $\mathrm{N}$ retention, the level of total $\mathrm{N}$ selected may have a great impact on the optimum $\mathrm{E}: \mathrm{T}$ value. At higher dietary $\mathrm{N}$ levels the requirement for essential $\mathrm{N}$ will be met at lower E:T values and consequently lower estimates of the optimum can be expected. Recent studies by Lenis et al. (1996) support this idea. Estimation of the optimum E:T value at a constant concentration of essential $\mathrm{N}$ seems to be a more suitable approach as it eliminates the confounding effect of dietary $\mathrm{N}$ level. Second, the present study has shown that the optimum E:T value required for maximum $\mathrm{N}$ retention differs from that for maximum $\mathrm{N}$ utilization. Current definitions of ideal protein do not distinguish between these criteria. Whereas the ideal pattern of essential amino acids is undoubtedly the same for both maximum $\mathrm{N}$ retention (or growth rate) and efficiency of $\mathrm{N}$ utilization (or minimum $\mathrm{N}$ excretion), the proportions of essential and non-essential amino acids are apparently different and the definition of ideal protein 
should reflect this fact. The third consideration relates to a possible effect of differences in E:T values required for maintenance and growth. No information on the optimum E:T value for maintenance has been reported in pigs or other species. However, the calculation based on the maintenance requirements for essential amino acids and the obligatory $\mathrm{N}$ loss in growing pigs as given by Fuller et al. (1989) suggests that the optimum E:T value for maintenance might be considerably lower than that for protein accretion. Since maintenance becomes relatively more important in older pigs, the resulting optimum E:T value might be affected. This problem deserves further study in order to define ideal protein more precisely.

The results reported herein suggest that optimization of the E:T value may substantially contribute to the reduction of $\mathrm{N}$ excretion. In a diet supplying sufficient quantities of essential amino acids allowing rapid growth such as in Expt 2, $\mathrm{N}$ excretion may be reduced by decreasing the concentration of total $\mathrm{N}$ up to the point at which nonessential $\mathrm{N}$ becomes limiting. As shown in Fig. 1, the breakpoint in $\mathrm{N}$ retention was identified at an E:T value of 0.48 . At this E:T value, calculated $\mathrm{N}$ excretion and dietary CP concentration were $0.65 \mathrm{~g} / \mathrm{kg}^{0.75}$ and $118 \mathrm{~g} / \mathrm{kg}$ respectively. This level of $\mathrm{N}$ excretion was substantially lower than those found in Expt 1 where diets contained $153 \mathrm{~g} \mathrm{CP} / \mathrm{kg}$.

The formulation of practical pig diets with E:T values close to 0.5 is hardly feasible, owing to the surplus of nonessential amino acids in most common cereals (E:T values typically near $0 \cdot 35-0 \cdot 4)$. In addition, when diets are formulated to meet essential amino acid requirements, several amino acids are provided in excess which should be included into the non-essential fraction, which causes a further decrease in the E:T value. Therefore, reducing the level of dietary $\mathrm{CP}$ and supplementation of amino acid deficiencies with crystalline amino acids will improve the utilization of dietary protein by improving the overall amino acid balance and by increasing the E:T value.

\section{Acknowledgements}

The authors appreciate the financial support of Degussa AG, Hanau, Germany and the critical review of the manuscript by Dr Brian J. Kerr, Nutri-Quest, Chesterfield, MO, USA. This work was supported by grant no. 505/94/0303 from the Grant Agency of the Czech Republic.

\section{References}

Adkins JS, Wertz JM \& Hove EL (1966) Influence of nonessential L-amino acids on growth of rats fed high levels of essential amino acids. Proceedings of the Society for Experimental Biology and Medicine 122, 519-523.

Agricultural Research Council (1981) The Nutrient Requirements of Pigs. Slough: Commonwealth Agricultural Bureaux.

Allen NK \& Baker DH (1974) Quantitative evaluation of nonspecific nitrogen sources for the growing chick. Poultry Science 53, 258-264.

Aqvist SEG (1951) Metabolic interrelationships among amino acids studied with isotopic nitrogen. Acta Chemica Scandinavica 5, 1046-1064.

Association of Official Analytical Chemists (1984) Official
Methods of Analysis, 14th ed. Washington, DC: Association of Official Analytical Chemists.

Baker DH (1997) Ideal Amino Acid Profiles for Swine and Poultry and their Applications in Feed Formulation. BioKyowa Technical Review no. 9. St. Louis, MO: Nutri-Quest, Inc.

Ball RD, Atkinson JL \& Bayley HS (1986) Proline as an essential amino acid for the young pig. British Journal of Nutrition 55, 659-668.

Bedford MR \& Summers JD (1985) Influence of the ratio of essential to non essential amino acids on performance and carcase composition of the broiler chick. British Poultry Science 26, 483-491.

Bikker P, Verstegen MWA \& Bosch M (1994) Amino acid composition of growing pigs is affected by protein and energy intake. Journal of Nutrition 124, 1961-1969.

Chung TK \& Baker DH (1992) Ideal amino acid pattern for 10-kilogram pigs. Journal of Animal Science 70, 3102-3111.

Chung TK \& Baker DH (1993) A note on the dispensability of proline for weanling pigs. Animal Production 56, 407-408.

Cieslak DG \& Benevenga NJ (1984a) The effect of amino acid excess on utilization by the rat of the limiting amino acid lysine. Journal of Nutrition 114, 1863-1870.

Cieslak DG \& Benevenga NJ (1984b) The effect of amino acid excess on utilization by the rat of the limiting amino acid lysine and threonine at equalized food intakes. Journal of Nutrition 114, 1878-1883.

Cole DJA \& Van Lunen TA (1994) Ideal amino acid patterns. In Amino Acids in Farm Animal Nutrition, pp. 99-112 [JPF D'Mello, editor]. Wallingford: CAB International.

D'Mello JPF (1994) Amino acid imbalances, antagonisms and toxicities. In Amino Acids in Farm Animal Nutrition, pp. 63-97 [JPF D'Mello, editor]. Wallingford: CAB International.

Fan MA, Sauer WC \& Lien KA (1994) Effect of dietary amino acid level on the determination of apparent ileal amino acid digestibility in pigs. In Proceedings of the VIth International Symposium on Digestive Physiology in Pigs, pp. 25-27 [WB Souffrant and H Hagemeister, Editors]. Dummerstorf: Forschungsinstitut fur die Biologie Landwirtschaftlicher Nutztiere.

Featherstone WR (1976) Adequacy of glutamic acid synthesis by the chick for maximal growth. Poultry Science 55, 2479-2480.

Fisher H, Griminger P, Leveille GA \& Shapiro R (1960) Quantitative aspects of lysine deficiency and amino acid imbalance. Journal of Nutrition 71, 213-220.

Frost DV \& Sandy HR (1951) Utilization of non-specific nitrogen sources by the adult protein-depleted rat. Journal of Biological Chemistry 189, 249-260.

Fuller MF (1994) Amino acid requirements for maintenance, body protein accretion and reproduction in pigs. In Amino Acids in Farm Animal Nutrition, pp. 155-184 [JPF D'Mello, editor]. Wallingford: CAB International.

Fuller MF, McWilliam R, Wang TC \& Giles LR (1989) The optimum dietary amino acid pattern for growing pigs. 2 . Requirements for maintenance and for tissue protein accretion. British Journal of Nutrition 62, 255-267.

Harper AE (1974) "Nonessential'" amino acids. Journal of Nutrition 104, 965-967.

Harper AE \& Benjamin E (1984) Relationship between intake and rate of oxidation of leucine and $\alpha$-isocaproate in vivo in the rat. Journal of Nutrition 114, 431-440.

Heger J (1990) Non-essential nitrogen and protein utilization in the growing rat. British Journal of Nutrition 64, 653-661.

Heger J \& Frydrych Z (1989) Efficiency of utilization of amino acids. In Absorption and Utilization of Amino Acids, pp. 31-56 [M Friedman, editor]. Boca Raton, FL: CRC Press.

Heger J, Frydrych Z \& Fronek P (1987) The effect of nonessential nitrogen on the utilization of dietary protein in the growing 
rat. Journal of Animal Physiology and Animal Nutrition 57, $130-139$.

Heger J, Mengesha S, Blaha J \& Koch F (1997) Estimation of minimum crude protein levels in diets for high-lean growth pigs. Agribiological Research 50, 64-77.

Kang-Lee YA \& Harper AE (1978) Effect of histidine intake and hepatic histidase activity on the metabolism of histidine in vivo. Journal of Nutrition 107, 1427-1443.

Kerr BJ \& Easter RA (1995) Effect of feeding reduced protein, amino acid-supplemented diets on nitrogen and energy balance in grower pigs. Journal of Animal Science 73, 3000-3008.

Kerr BJ, McKeith FK \& Easter RA (1995) Effect on performance and carcass characteristics of nursery to finisher pigs fed reduced crude protein, amino acid-supplemented diets. Journal of Animal Science 73, 433-440.

Kyriazakis I, Emmans GC \& McDaniel R (1993) Whole body amino acid composition of the growing pig. Journal of the Science of Food and Agriculture 62, 29-33.

Lenis NP, van Diepen JTM, Bakker JGM \& Jongbloed R (1996) Utilization of nitrogen and amino acids in growing pigs as affected by the ratio between essential and nonessential amino acids in the diet. Journal of Animal Science 74, Suppl. 1, 172.

Llames C \& Fontaine J (1994) Determination of amino acids in feeds: collaborative study. Journal of AOAC International 77, $1362-1402$.

Mitchell JR, Becker DE, Harmon G, Norton HW \& Jensen AH (1968) Some amino acid needs of young pigs, fed on semipurified and semisynthetic diet. Journal of Animal Science 27, $1322-1326$.

Morris TR (1989) The interpretation of response data from animal feeding trials. In Recent Developments in Poultry Nutrition, pp. 1-11 [DJA Cole and W Haresign, editors]. London: Butterworths.

Munro HN (1964) General aspects of the regulation of protein metabolism by diet and hormones. In Mammalian Protein Metabolism, vol. I, pp. 382-481 [HN Munro and JB Allison, editors]. New York, NY: Academic Press.

Noblet J (1996) Digestive and metabolic utilization of dietary energy in pig feeds: comparison of energy systems. In Recent Advances in Animal Nutrition 1996, pp. 207-231 [PC Garnsworthy, J Wiseman and W Haresign, editors]. Nottingham: Nottingham University Press.

Noblet J, Henry Y \& Dubois S (1987) Effect of protein and lysine levels in the diet on body gain composition and energy utilization in growing pigs. Journal of Animal Science 65, 717-726.

Petry H \& Rapp W (1970/71) Zur Problematik der ChromoxidBestimmung in Verdauungsversuchen (Determination of chromic oxide in digestibility experiments). Zeitschrift für Tierphysiologie, Tierernährung und Futtermittelkunde 27, 171-189.

Robbins KR, Norton HW \& Baker DH (1979) Estimation of nutrient requirements from growth data. Journal of Nutrition 109, 1710-1714.

Roth FX, Fickler J \& Kirchgessner M (1994a) N-Bilanz von Ferkeln bei vollstandigem Fehlen von einzelnen nichtessentiellen Aminosauren im Futter. 2. Mitteilung zur Bedeutung nicht-essentieller Aminosauren fur den Proteinansatz ( $\mathrm{N}$ balance of piglets as related to the omission of individual non-essential amino acids from the diet. 2. Communication on the importance of non-essential amino acids for protein retention). Journal of Animal Physiology and Animal Nutrition 72, 215-224.

Roth FX, Markert W \& Kirchgessner M (1994b) Zum Einfluss der Supplementierung von Niedrig-Protein-Rationen mit nichtessentiellen Aminosauren auf die N-Bilanz von Mastschweinen 3. Mitteilung uber Bilanzstudien zur Reduzierung der $\mathrm{N}$-Ausscheidung (Effects of adding non-essential amino acids to low-protein diets for growing pigs on $\mathrm{N}$ balance. 3. Communication on balance studies to reduce $\mathrm{N}$ excretion). Journal of Animal Physiology and Animal Nutrition 71, 76-86.

Rose WC, Oesterling MJ \& Womack M (1948) Comparative growth on diets containing ten and nineteen amino acids, with further observations upon the role of glutamic and aspartic acids. Journal of Biological Chemistry 176, 753-762.

Said AK \& Hegsted DM (1970) Response of adult rats to low dietary levels of essential amino acids. Journal of Nutrition $\mathbf{1 0 0}$, 1363-1375.

Shapiro R \& Fisher H (1962) Protein reserves: relationship of dietary essential and nonessential amino acids to formation maintenance in the fowl. Journal of Nutrition 76, 106-112.

Southern LL \& Baker DH (1983) Arginine requirement of the young pig. Journal of Animal Science 57, 402-412.

Steel RGD \& Torrie JH (1980) Principles and Procedures of Statistics: A Biometrical Approach, 2nd ed. New York, NY: McGraw-Hill Book Co.

Stucki WP \& Harper AE (1961) Importance of dispensable amino acids for normal growth of chicks. Journal of Nutrition 74, 377-383.

Stucki WP \& Harper AE (1962) Effects of altering the ratio of indispensable to dispensable amino acids in diets for rats. Journal of Nutrition 78, 278-286.

Sugahara M \& Ariyoshi S (1968) The role of dispensable amino acids for the maximum growth of chicks. Agricultural and Biological Chemistry 32, 153-160.

Tanaka H, Shibata K, Mori M \& Ogura M (1995) Metabolism of essential amino acids in growing rats at graded levels of soybean protein isolate. Journal of Nutritional Science and Vitaminology 41, 433-443.

Taylor TP, Morris JG, Willits NH \& Rogers QR (1996) Optimizing the pattern of essential amino acids as a sole source of dietary nitrogen supports near-maximal growth in kittens. Journal of Nutrition 126, 2243-2252.

Wang TC \& Fuller MF (1989) The optimum dietary amino acid pattern for growing pigs. 1. Experiments by amino acid deletion. British Journal of Nutrition 62, 77-89.

van Diepen JTH, Lenis NP, Klok G, Kogut J, van der Meulen J \& Bakker JGM (1995) Nitrogen and Amino Acid Utilization in Growing Pigs Fed Diets with Different Ratios of Essential to Non-essential Amino Acids. Report no. 284. Lelystad: DLO-Institute for Animal Science and Health.

Yamashita K \& Ashida K (1969) Lysine metabolism in rats fed lysine-free diet. Journal of Nutrition 99, 267-273. 